\title{
Inducible Permease Involved in the Uptake of Octopine, Lysopine and Octopinic Acid by Agrobacterium tumefaciens Strains Carrying Virulence-associated Plasmids
}

\author{
By P. M. KLAPWIJK, M. OUDSHOORN AND R. A. SCHILPEROORT \\ Department of Biochemistry, The University, Leiden, The Netherlands
}

(Received 17 January 1977; revised I April 1977)

\begin{abstract}
$\left[{ }^{3} \mathrm{H}\right]$ Octopine is transported by 'octopine' strains of Agrobacterium tumefaciens after induction by either octopine, lysopine or octopinic acid and by 'nopaline' strains after induction by nopaline. The analogues noroctopine, homo-octopine and desmethylhomooctopine had no inducing effect. Lysopine and octopinic acid showed a competitive influence on octopine uptake, as would be expected if there was one permease for all three compounds. The Michaelis-Menten constant for octopine transport was about $\mathrm{I}^{\circ} 5 \mu \mathrm{M}$. A sharp decline in transport activity was observed at $\mathrm{pH}$ values below $6 \cdot 0$. Evidence is provided that the octopine permease gene $(u a d B)$ and the accessory regulator gene (uadR) are carried by TI plasmids.
\end{abstract}

\section{INTRODUCTION}

Octopine, lysopine, octopinic acid and nopaline are amino-acid derivatives (Fig. I) detected in plant tumours induced by Agrobacterium tumefaciens (Smith and Townsend) Conn but not in healthy plant tissue. A tumour may contain either octopine, lysopine and octopinic acid or nopaline (Goldmann, Thomas \& Morel, 1969; Goldmann-Ménagé, 1970), depending on the type of virulence (TI) plasmid carried by the inducing bacteria (Bomhoff, 1974; Watson et al., I975; Bomhoff et al., 1976; Hooykaas et al., I977). The TI plasmids also carry genes that determine whether the bacteria can degrade octopine, lysopine and octopinic acid or nopaline: strains that evoke tumours containing nopaline are also able to degrade nopaline, while the others degrade octopine, lysopine and octopinic acid. Whether these observations can be explained by transfer of bacterial plasmid nucleic acids to plant cells during tumour induction has still to be determined (Lippincott \& Lippincott, 1975; Drlica \& Kado, I975; Kado, I976).

We are trying to compare the octopine-synthesizing enzyme isolated from tumour tissue with the degrading enzyme from the bacteria to see how they are related. In a previous report (Klapwijk et al., 1976) we described the isolation of several $A$. tumefaciens mutants altered in the utilization of octopine, lysopine and octopinic acid. These so-called Uad ${ }^{-}$mutants show an absolute coupling of the utilization of these three compounds. This phenomenon suggests that they are taken up and degraded by a common system. The mutants were most likely defective in the octopine oxidase gene(s) yet they were still able to induce tumours containing octopine. These observations were confirmed by Tempé (unpublished results) and by Montoya et al. (1977). Therefore if there is gene transfer from the bacteria to plant cells during tumour induction and the genes responsible for octopine synthesis in the plant are of bacterial origin, they are not identical to the octopine oxidase gene(s) in the bacterium. More information about the regulation and number of uad genes involved in the bacterial degradation of amino-acid derivatives is required, not only to clarify these results,

Vol. 101, No. 2, was issued 24 August 1977 
<smiles>CC(NC(CCN)C(=O)O)C(=O)O</smiles>

D-octopinic acid<smiles>CC(NC(CCN)C(=O)O)C(=O)O</smiles>

D-lysopine<smiles>CC(NC(CCCCCCCCCCCC(=N)N)C(=O)O)C(=O)O</smiles><smiles>CC(NC(CCNC(=N)N)C(=O)O)C(=O)O</smiles>

D-homo-octopine<smiles>N=C(N)NCCC(NCC(=O)O)C(=O)O</smiles>

noroctopine<smiles>N=C(N)NCCC(NCC(=O)O)C(=O)O</smiles>

desmethylhomo-octopine<smiles>N=C(N)NCCCCC(N)C(=O)O</smiles>

L-arginine<smiles>N=C(N)NCCC(NC(CCC(=O)O)C(=O)O)C(=O)O</smiles>

D-nopaline

Fig. I. Structural formulae of the amino-acid derivatives used in this study.

but also because recently it has been found that octopine stimulates the transfer of the TI plasmids between Agrobacterium strains (Genetello et al., I977; Kerr, Manigault \& Tempé, 1977).

We assume that there are four factors involved in the utilization of the above mentioned amino-acid derivatives as bacterial nitrogen sources: (i) induction; (ii) uptake by a permease; (iii) splitting into amino acid and $\alpha$-keto acid by an oxidase; and (iv) degradation of the amino acid by catabolic enzymes. We describe here the role of induction and uptake of amino-acid derivatives and provide evidence that both functions are coded for by the TI plasmid genes.

\section{METHODS}

Bacterial strains are listed in Table I. All incubations were carried out at $29{ }^{\circ} \mathrm{C}$. The wild-type strains were checked by phage typing (Van Larebeke et al., 1975).

Media. The minimal medium (SM) contained $\left(\mathrm{g} \mathrm{1}^{-1}\right): \mathrm{K}_{2} \mathrm{HPO}_{4}, 10 \cdot 25 ; \mathrm{KH}_{2} \mathrm{PO}_{4}, 7 \cdot 25 ;\left(\mathrm{NH}_{4}\right)_{2} \mathrm{SO}_{4}, 3 \cdot 0$; $\mathrm{MgSO}_{4} .7 \mathrm{H}_{2} \mathrm{O}, 0.50 ; \mathrm{NaCl}, 0 \cdot 15 ; \mathrm{CaCl}_{2} .6 \mathrm{H}_{2} \mathrm{O}, 0.1 ; \mathrm{FeSO}_{4} .7 \mathrm{H}_{2} \mathrm{O}, 0.0025 ;$ and glucose, $4 \cdot 0$. When octopine or another compound was used as the sole source of nitrogen, $\left(\mathrm{NH}_{4}\right)_{2} \mathrm{SO}_{4}$ was omitted (SM-N medium).

Cultures ( $10 \mathrm{ml}$ ) were grown in $100 \mathrm{ml}$ Erlenmeyer flasks in a linear shaker. Turbidity (as $E_{666}$ ) was used as a measure of the number of organisms $\mathrm{ml}^{-1}$; the relation between them was determined by plating serial dilutions of known $E_{666}$. The dry weight of $10^{8}$ organisms of strain $86 \mathrm{~s} 3$ grown in SM was $30 \mu \mathrm{g}$. The protein content of lyophilized bacteria was $52 \%$ when determined by the method of Lowry et al. (1951) using bovine serum albumin as a standard.

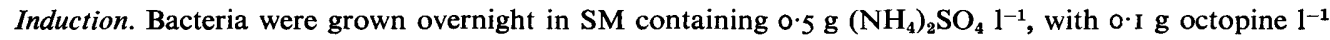
or an equal amount of one of the other compounds. Uninduced cultures were grown in SM without further additions.

Determination of octopine uptake. Cultures were grown overnight, diluted with an equal volume of fresh medium and incubated for another $150 \mathrm{~min}$. The bacteria were harvested by centrifuging and resuspended 


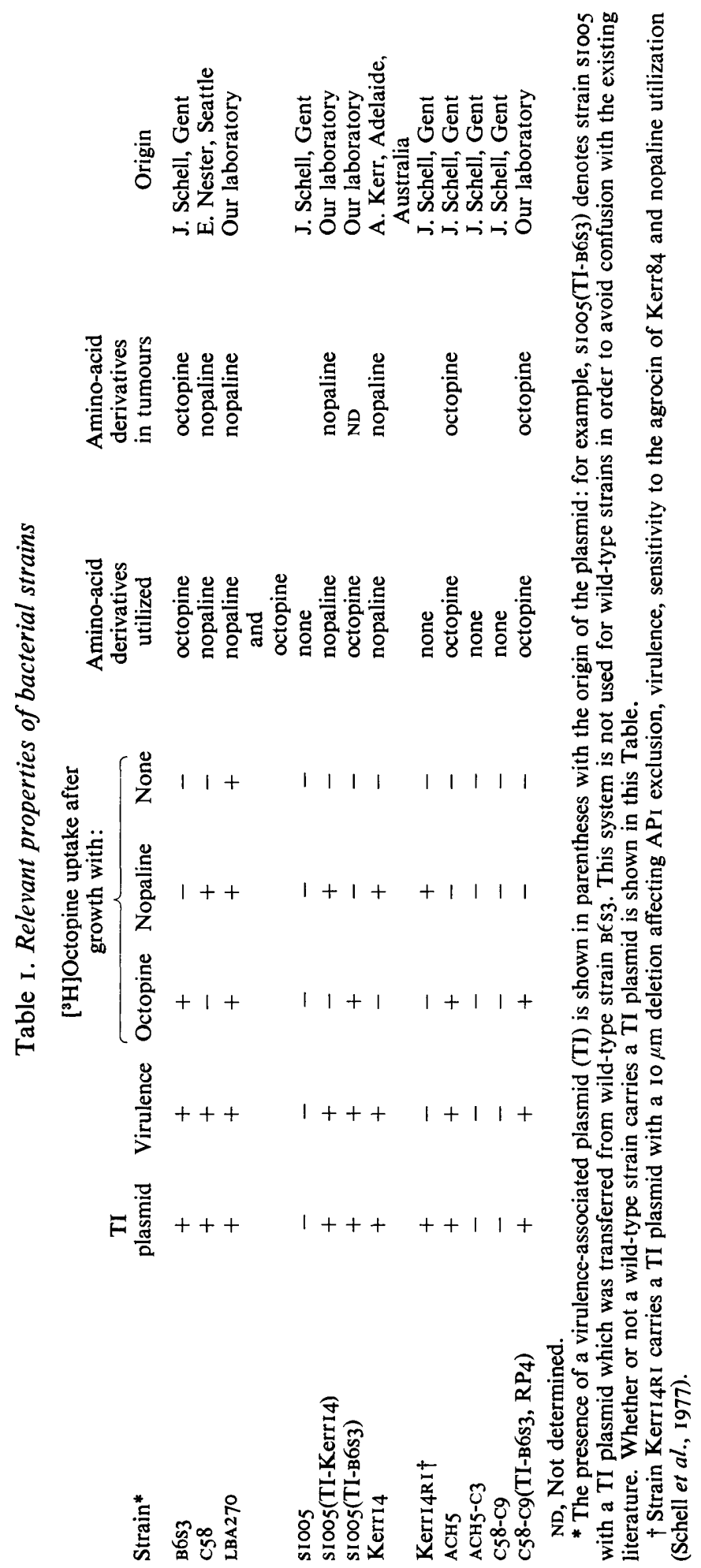


in SM-N at $5 \times 10^{8}$ organisms $\mathrm{ml}^{-1}$. To this bacterial suspension [ $\left.{ }^{3} \mathrm{H}\right]$ octopine was added to a final concentration of $8.5 \mu \mathrm{M}\left(6.75 \mu \mathrm{Ci} \mu \mathrm{mol}^{-1}\right)$. Samples $(0.25 \mathrm{ml})$ were taken at $\mathrm{o}, \mathrm{I}, 2,4$ and $6 \mathrm{~min}$, immediately diluted with $5 \mathrm{ml} 0.9 \%(\mathrm{w} / \mathrm{v}) \mathrm{NaCl}$, filtered on a Millipore filter ( $0.45 \mu \mathrm{m}$ pore size) and washed with $20 \mathrm{ml} 0.9 \%$ $\mathrm{NaCl}$. The filters were dried and counted with $8 \mathrm{ml} 0.4 \%$ (w/v) 2,5-diphenyloxazole (PPO; Merck) in toluene. Arginine uptake was determined in the same way, but using $\mathrm{I} \times 1 \mathrm{I}^{8}$ organisms $\mathrm{ml}^{-1}$ and $\left[{ }^{3} \mathrm{H}\right]$ arginine at $58 \mu \mathrm{M}\left(35 \mu \mathrm{Ci} \mu \mathrm{mol}^{-1}\right)$.

To determine the quantity of $\left[{ }^{3} \mathrm{H}\right]$ octopine taken up by the bacteria, the dried filters with the bacteria were solubilized with I $\mathrm{ml}$ Soluene (Packard) per filter for $\mathrm{I} 5 \mathrm{~min}$. Then 0. I $\mathrm{ml} 30 \%(\mathrm{w} / \mathrm{v}) \mathrm{H}_{2} \mathrm{O}_{2}$ was added, followed after $3 \mathrm{~h}$ by $13 \mathrm{ml}$ toluene/Triton X-100 (3:I, v/v) containing $0.4 \%$ PPO. After vigorous shaking the samples were counted and the d.p.m. were calculated using the counting efficiency determined with an external standard.

Variation of the $\mathrm{pH}$ value of the medium. For determination of the effect of $\mathrm{pH}$ on $\left[{ }^{3} \mathrm{H}\right]$ octopine uptake, the usual phosphate addition to the incubation medium was omitted and different ratios of $\mathrm{KH}_{2} \mathrm{PO}_{4}(9.08 \mathrm{~g}$ $\mathrm{I}^{-1}$ ) and $\mathrm{Na}_{2} \mathrm{HPO}_{4}\left(\mathrm{I} \cdot 88 \mathrm{~g}^{-1}\right.$ ) were added (Sørensen's phosphate buffer; Sober, 1970). The total concentration of phosphate was $0.067 \mathrm{M}$. In other experiments McIlvaine citrate/phosphate buffer (Sober, 1970) was used at one-tenth of its original strength.

Competition with octopine uptake. The usual concentration of $\left[{ }^{3} \mathrm{H}\right]$ octopine was added to the incubation mixture and uptake was determined over $6 \mathrm{~min}$ in a series of cultures to which increasing amounts of the compound being tested for competition were added. A reference line was determined by adding unlabelled octopine.

Chemicals. $\left[{ }^{3} \mathrm{H}\right] \mathrm{Octopine}$ was synthesized from $\mathrm{L}-\left[\beta-{ }^{3} \mathrm{H}\right]$ arginine and 2 -bromopropionic acid following the procedure of Bomhoff (1974). The product was purified by column chromatography using BioRad anionic exchanger Ag-2-X8 and subsequent preparative paper electrophoresis as previously described (Bomhoff, 1974; Schilperoort \& Bomhoff, 1975). The final product was more than $99 \%$ pure.

Homo-octopine was synthesized from L-homoarginine (Koch-Light) and 2-bromopropionic acid (Merck, zur Synthese) following the procedure of Bomhoff (1974). Desmethylhomo-octopine was synthesized by mixing equimolar amounts of L-homoarginine and bromoacetic acid (Merck, zur Synthese) in water in the presence of excess $\mathrm{Ba}(\mathrm{OH})_{2}$. The reaction at $37^{\circ} \mathrm{C}$ was allowed to proceed for $72 \mathrm{~h}$. Desmethylhomooctopine and homoarginine were separated by column chromatography with Dowex anionic exchanger $50 \mathrm{~W}-\mathrm{X} 8,100$ to 200 mesh (H. C. M. Kester, unpublished results).

Lysopine and noroctopine were generous gifts from Dr B. Lejeune, Orsay, France and Dr J. Tempé, Versailles, France, respectively. D-Nopaline was a gift from Dr M. van Montagu, Brussels, Belgium. L-Arginine, L-serine, L-lysine and D-alanine were from Merck. $\mathrm{L}-\left[\beta_{-}{ }^{3} \mathrm{H}\right]$ Arginine was obtained from New England Nuclear. $\mathrm{D}(+)$-Octopine and $\mathrm{D}(+)$-octopinic acid were from Sigma. Oxytetracycline was from Mycofarm, Delft, The Netherlands.

Symbols. $\mathrm{Uad}^{-}$is used to designate strains that are not able to utilize the amino-acid derivatives octopine, lysopine and octopinic acid, but are unaffected in the utilization of the corresponding amino acids (Klapwijk et al., 1976).

\section{RESULTS}

\section{General properties of the octopine uptake by strain $\mathrm{B} 6 \mathrm{~s} 3$}

When an exponentially growing culture of $A$. tumefaciens $\mathrm{B} 6 \mathrm{~s} 3$ was harvested and inoculated into fresh medium containing octopine, there was no lag phase in the disappearance of octopine from the medium if the bacteria had previously been grown in medium containing octopine as a nitrogen source, but there was a lag phase of $30 \mathrm{~min}$ if the bacteria had been grown with arginine (Fig. 2). Therefore the enzymes responsible for the conversion of octopine into arginine and pyruvate may need to be induced. Octopine uptake was shown to depend on induction (Fig. 3), and was not observed until 40 min after the addition of octopine (Fig. 4). No induction of uptake was observed when an inhibitor of protein synthesis, such as tetracycline, was added simultaneously (Fig. 4).

The uptake of octopine was dependent on the external concentration of this compound and showed saturation as would be expected for an enzyme-catalysed process. The Michaelis-Menten constant $\left(K_{\mathrm{m}}\right)$ was $\mathrm{I} \cdot 5 \pm 0 \cdot 2 \mu \mathrm{M}$. A Lineweaver-Burk plot showed a linear relationship between $v^{-1}$ and $s^{-1}$; only at low $s^{-1}$ values was there some divergence. The $V_{\max }$ of the uptake system was about Io $\mathrm{nmol} \mathrm{mg}^{-1} \mathrm{~min}^{-1}$. This value is higher than that for lysopine transport by the closely related $A$. tumefaciens strain $\mathrm{B} 6$ (I.4 $\mathrm{nmol} \mathrm{mg}^{-1} \mathrm{~min}^{-1}$; Jubier, 1975). 


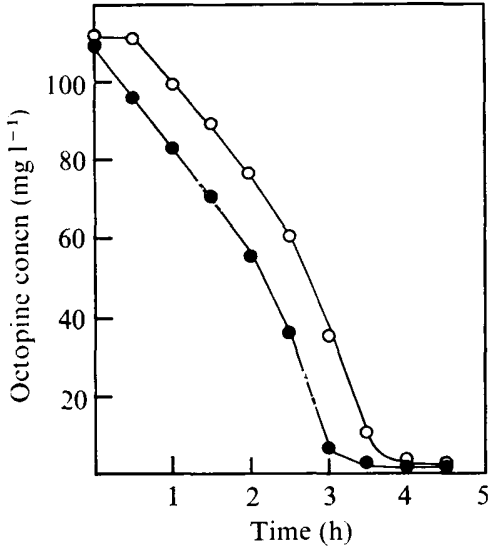

Fig. 2

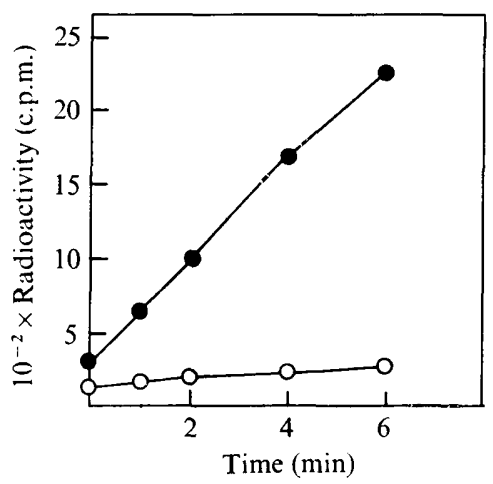

Fig. 3

Fig. 2. Disappearance of octopine from the medium of cultures of strain B6s3. Exponential-phase

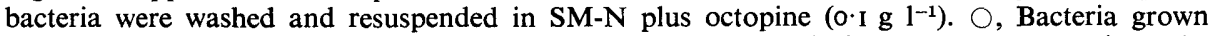
previously in SM-N plus arginine;, bacteria grown previously in SM-N plus octopine. The octopine concentration was measured as described by Bomhoff (1974) using $\alpha$-naphthol-diacetyl reagent.

Fig. 3. Uptake of $\left[{ }^{3} \mathrm{H}\right]$ octopine by strain $\mathbf{8} 6 \mathrm{~s}_{3}$, measured as described in Methods. $\bigcirc$, Uninduced culture; $\mathbf{O}$, culture induced by growth with octopine $\left(0 \cdot \mathrm{I}^{\left.\mathbf{~ l}^{-1}\right)}\right.$.

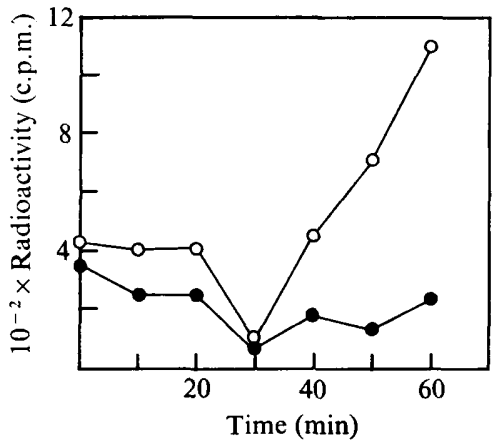

Fig. 4

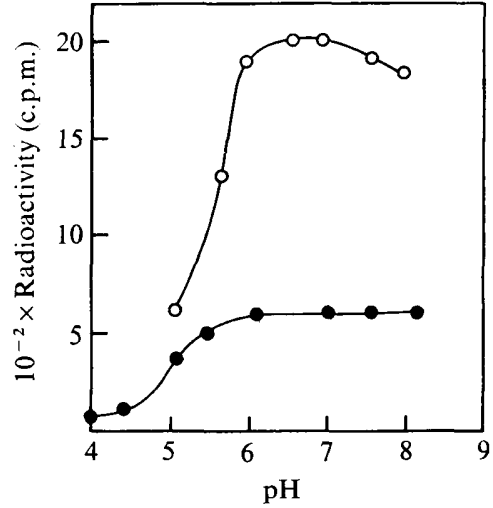

Fig. 5

Fig. 4. Induction of octopine uptake activity in strain B6s3. At time o, octopine ( $10 \mathrm{mg} \mathrm{l}^{-1}$, final concentration) or octopine and oxytetracycline $\left(5 \mathrm{mg} \mathrm{l}^{-1}\right.$, final concentration) were added to an exponentially growing culture in SM. Samples were withdrawn immediately and at 10 min intervals, and the bacteria were separated by centrifuging ( $5 \mathrm{~min}, 4000 \mathrm{~g}$ ) and resuspended in SM-N. $\left[{ }^{3} \mathrm{H}\right]$ Octopine uptake was determined over $5 \mathrm{~min}$ as described in Methods. 0 , Octopine added alone; octopine and oxytetracycline added.

Fig. 5. Influence of the $\mathrm{pH}$ of the medium on octopine uptake activity. $\left[{ }^{3} \mathrm{H}\right]$ Octopine uptake was determined over $6 \mathrm{~min}$ in a series of cultures at different $\mathrm{pH} . \bigcirc, 0.067 \mathrm{~m}$ Sørensen phosphate buffer; - Mcllvaine citrate/phosphate buffer.

Bomhoff (1974) reported that octopine utilization can be inhibited if the medium is not adequately buffered. Glucose-grown bacteria regularly produce acid which lowers the $\mathrm{pH}$ of the medium. We found that when the $\mathrm{pH}$ of the medium was varied by the addition of different phosphate buffers, there was a sharp decline in uptake activity at $\mathrm{pH}$ values below 6.0 (Fig. 5). The fact that in McIlvaine buffer (citrate/phosphate) there was less octopine uptake over the whole $\mathrm{pH}$ range may be explained by chelation of $\mathrm{Mg}^{2+}$ by citrate; the decrease could be compensated by adding more $\mathrm{MgSO}_{4}$. 
Table 2. Induction of $\left[{ }^{3} \mathrm{H}\right]$ octopine uptake by different substrates Bacteria were grown in the presence of the test compound $\left(0 \cdot 1 \mathrm{~g} \mathrm{I}^{-1}\right)$, washed and their
uptake of $\left[{ }^{3} \mathrm{H}\right]$ octopine over $5 \mathrm{~min}$ was measured as described in Methods.

$\begin{aligned} & \text { Compound added to } \\ & \text { medium }\end{aligned}$
Octopine
Lysopine
Octopinic acid
Nopaline
Arginine
Lysine
Noroctopine
Desmethylhomo-octopine
Homo-octopine
None

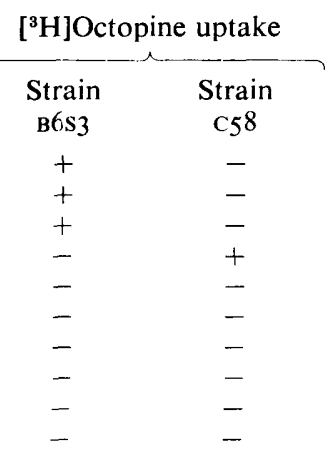

\section{Specificity of induction}

Our hypothesis that octopine, lysopine and octopinic acid are degraded by a single system in $A$. tumefaciens B $6 \mathrm{~s} 3$ requires that the uptake system, which is essential for utilization, must be inducible by each of these three compounds. We observed uptake of $\left[{ }^{3} \mathrm{H}\right]-$ octopine after growth with either octopine, lysopine or octopinic acid, but not after growth with nopaline (Table 2). In strain $\mathrm{C} 58$, octopine uptake was only induced by nopaline (Table 2, Fig. 9). The synthetic analogues and amino acids tested had no inducing effect (Table 2). Therefore octopine uptake is only induced when the natural substrates that are found in the tumour are added to the culture - nopaline for a 'nopaline' strain, and octopine, lysopine or octopinic acid for an 'octopine' strain.

\section{Competition for sites of the uptake system}

If there were only one system for octopine, lysopine and octopinic acid utilization in 'octopine' strains, the three compounds would be taken up by a single permease and the presence of one of the compounds would influence the uptake rate of another. Because the supply of $\left[{ }^{3} \mathrm{H}\right]$ octopine was limited we could not test this hypothesis by performing classical competition experiments. We therefore developed a probe method in which we used a fixed concentration of $\left[{ }^{3} \mathrm{H}\right]$ octopine in the uptake medium and added increasing amounts of the competitor, using the effect of unlabelled octopine as a reference. If the addition of a given amount of a competitor had the same influence on the rate of $\left[{ }^{3} \mathrm{H}\right]$ octopine uptake as an equimolar amount of unlabelled octopine, it seemed reasonable to assume that the octopine permease had the same affinity for the competitor as for octopine.

The octopine-transporting permease appeared to have the same degree of affinity for lysopine, octopinic acid and octopine (Fig. 6 a). The presence of L-arginine, L-lysine, L-serine or D-alanine in the incubation medium had little effect on the uptake of octopine (Fig. $6 b$ ), indicating that the octopine permease has no affinity for these compounds. Conversely, the presence of an excess of unlabelled octopine had no effect on the rate of $\left[{ }^{3} \mathrm{H}\right]$ arginine uptake (Fig. 7).

The Uad- mutant LBAIO2 (Klapwijk et al., 1976) showed no uptake of octopine, whereas arginine uptake was normal. This suggests that the uptake of octopine, lysopine and octopinic acid in 'octopine' strains (like $\mathrm{B}_{\mathrm{6}} 3$ ) is carried out by a single permease, which is not that utilized by the bacteria for the transport of arginine or the other amino acids tested.

The nopaline-degrading strain $\mathrm{C} 58$ took up $\left[{ }^{3} \mathrm{H}\right.$ ]octopine after induction by growth with nopaline (Table 2) and the uptake was influenced by the presence of nopaline in the medium. However, uptake of octopine by strain $\mathrm{B}^{6} \mathrm{~s} 3$ was not sensitive to the addition of excess 

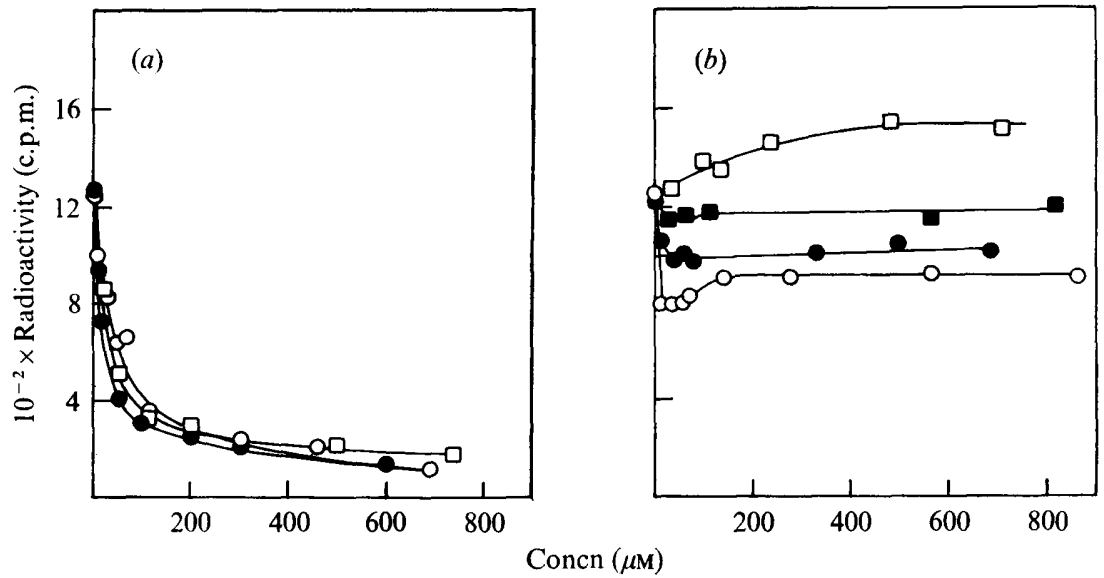

Fig. 6. Competition for sites of the uptake system. Strain B6s3, grown in SM plus octopine (0.I g $\left.1^{-1}\right)$, was incubated with a fixed concentration of $\left[{ }^{3} \mathrm{H}\right]$ octopine $(8 \cdot 5 \mu \mathrm{M})$ and increasing amounts of the compound being tested for competition. Unlabelled octopine was added in one series of experiments to obtain a reference line. (a) $\bigcirc$, lysopine; $\bigcirc$, octopine; $\square$, octopinic acid. $(b) \bigcirc, \mathrm{L}$-arginine; , L-lysine; $\square$, L-serine; $\mathbf{u}, \mathrm{D}$-alanine.

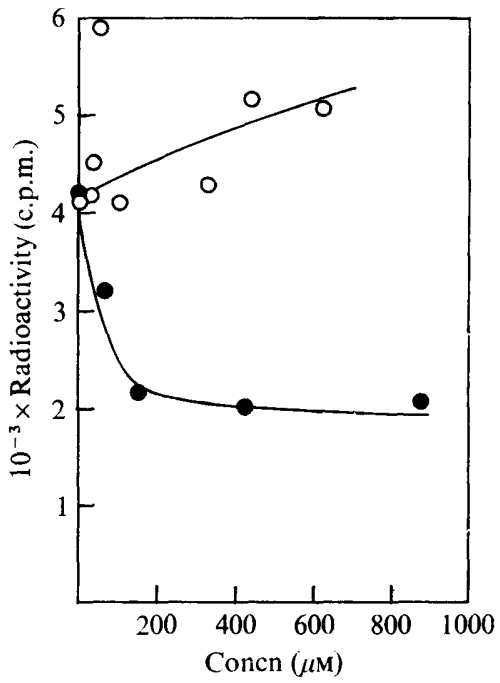

Fig. 7

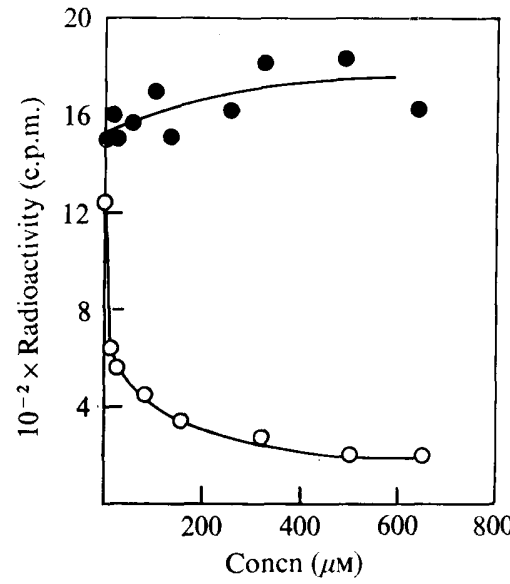

Fig. 8

Fig. 7. Influence of unlabelled octopine on the uptake of $\left[{ }^{3} \mathrm{H}\right]$ arginine by strain $\mathrm{B} 6 \mathrm{~s} 3$. The bacteria were incubated with a fixed concentration of $\left[{ }^{3} \mathrm{H}\right]$ arginine and increasing amounts of octopine $(O)$ or arginine (O).

Fig. 8. Effect of nopaline in the medium on the uptake of $\left[{ }^{3} \mathrm{H}\right]$ octopine. The bacteria were incubated with a fixed concentration of $\left[{ }^{3} \mathrm{H}\right]$ octopine and increasing amounts of nopaline. $\bigcirc$, Strain $\mathrm{C}_{5} 8$, induced by growth with nopaline; $O$, strain $\mathrm{B} 6 \mathrm{~s}_{3}$, induced by growth with octopine.

unlabelled nopaline (Fig. 8). It seems that the permease of strain $\mathrm{C}_{5} 8$ has affinity for both octopine and nopaline, whereas that in $\mathrm{B}_{6} \mathrm{~S} 3$ accepts octopine but not nopaline. Nopalinedegrading strains such as $\mathrm{C}_{58} 8$ and Kerri 4 can only utilize nopaline, but mutants that can also utilize octopine have been isolated (Petit \& Tempé, 1975; Hooykaas et al., 1977). Petit \& Tempé postulated that these mutants produced the nopaline enzymes constitutively. An octopine-utilizing variant of $\mathrm{C}_{5} 8$ (strain LBA270) showed a spontaneous uptake of $\left[{ }^{3} \mathrm{H}\right]-$ octopine comparable to that of $\mathrm{C}_{5} 8$ induced by growth with nopaline (Fig. 9). This uptake was equally sensitive to the addition of unlabelled nopaline. 


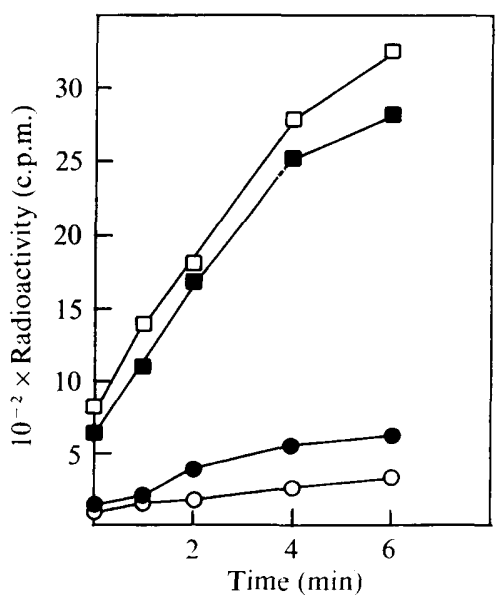

Fig. 9

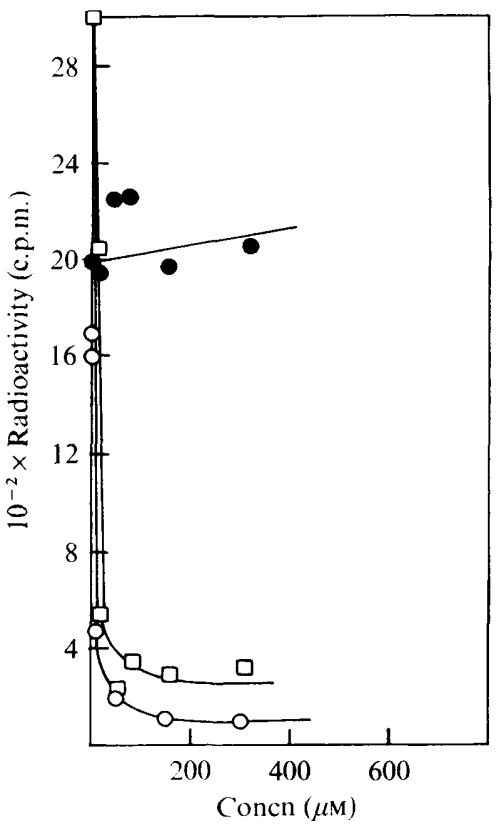

Fig. 10

Fig. 9. Uptake of $\left[{ }^{3} \mathrm{H}\right]$ octopine by strain $\mathrm{C}_{5} 8$ and its octopine-utilizing variant LBA270. $\bigcirc, \mathrm{C}_{5} 8$ grown with octopine;, $\mathrm{C} 58$ grown without nopaline or octopine; $\square$, $c 58$ grown with nopaline; ש. LBA270 grown without nopaline or octopine.

Fig. IO. Effect of nopaline in the medium on the uptake of $\left[{ }^{3} \mathrm{H}\right]$ octopine by strains with TI plasmids of different origins. Conditions were comparable to those in Fig. 8. O, sioos(TI-Kerr I4), induced by growth with nopaline;, , sio05(TI-B6s3) induced by growth with octopine; $\square$, Kerr I4, induced by growth with nopaline.

Therefore it seems that the specificity of utilization of amino-acid derivatives by strain C58 is determined by the regulatory process and not by the permease or the oxidase. This is consistent with the observation that LBA270 not only used octopine and nopaline, but also lysopine, octopinic acid and noroctopine.

\section{Evidence that the genes for octopine permease and the accessory regulatory protein are located on the TI plasmids}

A previous report (Hooykaas et al., 1977) showed that the ability to utilize octopine could be transferred with the TI plasmid of A. tumefaciens strain $\mathrm{B}^{6} \mathrm{~s}_{3}$ to Rhizobium trifolii. This indicates that all the genes essential for octopine degradation are located on the TI plasmid, unless we assume that some uad genes were already present in $R$. trifolii. The latter seems unlikely because, to the best of our knowledge, there are no reports of octopine or nopaline utilization in Rhizobium strains.

We have shown that octopine uptake can be induced by octopine, lysopine and octopinic acid or by nopaline, depending on the strain under study, and we wanted to confirm that this regulation was under the control of plasmid genes. We therefore studied several isogenic strains carrying TI plasmids of different origins, and found that the response of a strain to induction by either octopine or nopaline correlated with the origin of the plasmid and was independent of the chromosomal background (Table I). Strain sioo5(TI-KerrI4), for example, reacted like Kerri 4 to nopaline, while sioo5(TI-B6s3) reacted to octopine like B6s3. Thus the regulation of the synthesis of octopine permease must be determined by a gene $(\operatorname{uadR})$ on the TI plasmids.

An indication that the gene for octopine permease is also plasmid-borne is the absence of 
octopine uptake activity in plasmid-less strains such as $\mathrm{C}_{5}^{8-\mathrm{C} 9}$ and $\mathrm{ACH} 5-\mathrm{C} 3$. The possibility that transcription of a chromosomal permease is activated by a plasmid-borne regulatory gene is unlikely on the following grounds. As already mentioned, we found an important difference between $\mathrm{B}_{6 \mathrm{~s}} 3$ and $\mathrm{C}_{5} 8$ in the effect of nopaline on octopine uptake: uptake of octopine in $\mathrm{B}^{6} \mathrm{~s} 3$ was insensitive to the presence of nopaline, while uptake by C58 was very sensitive to nopaline (Fig. 8). We therefore examined strains to see if the permease of a given strain showed the same degree of sensitivity to nopaline as that of another with the same TI plasmid. We found this was so: strain sioo5(TI-Kerr I4), which like KerrI4 and $\mathrm{c}_{5} 8 \mathrm{had}$ the capacity to utilize nopaline, had a permease that took up octopine and that was sensitive to nopaline, whereas strain sı 005 (TI-B6s 3 ), like $\mathrm{B}_{6} \mathrm{~s}_{3}$, had a permease insensitive to nopaline (Fig. IO). These observations suggest that the octopine permease is coded for by a TI plasmid-borne gene $(\mathrm{uadB})$ and was transferred with the TI plasmid gene from one strain to the other.

\section{Strain KerrI4 with a deleted TI plasmid}

By selection for clones resistant to agrocin $\mathrm{K} 84$, Schell et al. (I977) isolated several Agrobacterium mutants with deletions in the TI plasmid. One of these strains, mutant KerrI4RI, was unable to grow on nopaline as sole source of nitrogen, was avirulent and was no longer able to exclude bacteriophage API; it had a deletion of up to $10 \mu \mathrm{m}$ in the TI plasmid. It seemed likely that one or more components of the nopaline degradation system were missing in this strain. However, after induction by growth with nopaline, it took up $\left[{ }^{3} \mathrm{H}\right]-$ octopine. Thus the regulator gene and the permease gene were still present and were located outside the deleted region, whereas one or more genes responsible for the synthesis of an active nopaline oxidase had disappeared with the deletion.

\section{DISCUSSION}

Our results are consistent with the hypothesis that genes located on the TI plasmids in A. tumefaciens are responsible for the synthesis and the regulation of a permease with high affinity for both nopaline and octopine or for octopine alone. They support our opinion that all specific uad genes are localized on the TI plasmid. This opinion is based not only on TI transfer between agrobacteria (Bomhoff et al., 1976) and into Rhizobium (Hooykaas et al., 1977), but also on the fact that with a cointegrate consisting of the TI plasmid and the $\mathrm{R}$ factor $\mathrm{RP}_{4}$ it could be proven that $\mathrm{Uad}^{-}$mutations are located on the TI plasmid (Klapwijk, unpublished results). The results are also in agreement with our experiments with Uad- mutants (Klapwijk et al., I976) which indicated that octopine, lysopine and octopinic acid share one common degradation system.

We have shown that octopine-utilizing variants of 'nopaline' strains produce the permease constitutively. This confirmed the work of Petit \& Tempé (1975) who postulated that these octopine-utilizing strains were constitutive. It seems that whether a compound will be degraded depends on the specificity of the inducing regulatory system. Once the system is induced or constitutively present it may accept related compounds. Thus the mutant of C58 (LBA270) was able to grow equally well on octopine, lysopine, octopinic acid and noroctopine. The low $K_{\mathrm{m}}$ value of the octopine permease coded for by the TI plasmid present in $\mathrm{B}_{6} \mathrm{~s} 3$ means that this is a high affinity permease compared with other amino-acid permeases (Oxender, 1972). We found that the activity of the octopine permease is influenced by the $\mathrm{pH}$ of the medium and that it is not detectable in rich media. In addition we never observed degradation of octopine in media with high concentrations of amino acids. These considerations must, therefore, be taken into account when determining whether a strain can utilize octopine, nopaline or related compounds.

Although octopine stimulates both the expression of octopine enzymes and the transfer of TI plasmids (Genetello et al., 1977), the relation between these phenomena remains an open question. That there is a common factor can be deduced from the enhanced TI 
transfer frequency in constitutive mutants (Kerr et al., I977). If the common factor is one repressor for both transfer and uad genes, there may be two types of constitutive mutants one with normal TI transfer and increased levels of octopine enzymes (operator mutants) and another type with high TI transfer and also high levels of octopine enzymes (repressor mutants). Constitutive derivatives of both 'nopaline' and 'octopine' strains have been isolated. This indicates that there is only one repressor for all uad genes and that mutation of the repressor relieves both the permease and the oxidase genes. If these uad genes were in an operon and thus closely linked, a very big deletion (as in Kerr I4RI) should cause the loss of all uad genes. Since this did not occur in KerrI4RI, it is unlikely that the uad genes are in one operon.

The method for measuring octopine permease activity described here permits an easy survey of the factors that influence expression of the plasmid-borne octopine genes.

This work was partly sponsored by the Netherlands Foundation for Chemical Research (SON) with financial aid from the Netherlands Organization for the Advancement of Pure Research (ZWO). We appreciated stimulating discussions with Dr P. J. J. Hooykaas.

\section{REFERENCES}

Boмнoff, G. H. (1974). Studies on crown gall-a plant tumour. Investigations on protein composition and on the use of guanidine compounds as a marker for transformed cells. Thesis, University of Leiden, The Netherlands.

Bomhoff, G. H., KLAPWiJk, P. M., Kester, H. C. M., Schilperoort, R. A., Hernalsteens, J. P. \& SChell, J. (1976). Octopine and nopaline: synthesis and breakdown genetically controlled by a plasmid of Agrobacterium tumefaciens. Molecular and General Genetics 145, 177-181.

Drlica, K. A. \& Kado, C. I. (1975). Crown gall tumors: are bacterial nucleic acids involved? Bacteriological Reviews 39, 186-196.

Genetello, C., Larebeke, N. van, Holsters, M., Picker, A. De, Montagu, M. van \& Schell, J. (1977). The TI plasmids of Agrobacterium as sex factors. Nature, London $265,56 \mathrm{I}-563$.

Goldmann, A., Thomas, D. W. \& Morel, G.(1969). Sur la structure de la nopaline métabolite anormal de certaines tumeurs de crown gall. Comptes rendus hebdomadaire des séances de l'Académie des sciences 268, 852-854.

Goldmann-MÉnAGÉ, A. (1970). Recherches sur la métabolisme azoté des tissus de Crown gall cultivés 'in vitro'. Thesis, Université de Paris, France.

Hooykaas, P. J. J., KlapwiJk, P. M., Nuti, M. P., Schilperoort, R. A. \& RörsCh, A. (1977). Transfer of the Agrobacterium tumefaciens TI plasmid to avirulent agrobacteria and to Rhizobium ex planta. Journal of General Microbiology 98, 477-484.

JUBIER, M. F. (1975). Recherches sur le métabolisme de la lysopine par Agrobacterium tumefaciens. Relation avec le problème du Crown gall. Thesis, Université de Paris-Sud, France.

Kado, C. I. (1976). The tumor-inducing substance of Agrobacterium tumefaciens. Annual Review of Phytopathology 14, 265-308.

Kerr, A., Manigault, P. \& Tempé, J. (I977). Agrobacterium: transfer of virulence in vivo and in vitro. Nature, London, 265, 560-56I.
KlapwiJk, P. M., HoOykaAs, P. J. J., Kester, H. C. M., Schilperoort, R. A. \& Rörsch, A. (1976). Isolation and characterization of Agrobacterium tumefaciens mutants affected in the utilization of octopine, octopinic acid and lysopine. Journal of General Microbiology 96, I55163.

Larebeke, N. van, Genetello, Ch., Schell, J., Schilperoort, R. A., Hermans, A. K., HernalSTEEns, J. P. \& Montagu, M. VAN (1975). Acquisition of tumor inducing ability by nononcogenic Agrobacteria as a result of plasmid transfer. Nature, London 255, 742-743.

LippincotT, J. A. \& LipPincoTt, B. B. (I975). The genus Agrobacterium and plant tumorigenesis. Annual Review of Microbiology 29, 377405.

Lowry, O. H., Rosebrough, N. J., Farr, A. L. \& Randall, R. J. (I95I). Protein measurement with Folin phenol reagent. Journal of Biological Chemistry 193, 265-275.

Montoya, A. L., Chilton, M. D., Gordon, M. P., SCIAKY, D. \& Nester, E. W. (1977). Octopine and nopaline metabolism in Agrobacterium tumefaciens and Crown gall tumor cells: role of plasmid genes. Journal of Bacteriology 129, IOI-IO7.

OXENDER, D. L. (1972). Membrane transport. Annual Review of Biochemistry 41, 777-814.

Petit, A. \& Tempé, J. (I975). Étude du métabolisme des guanidines des tissus de Crown-gall par la souche T37 d'Agrobacterium tumefaciens. Comptes rendus hebdomadaire des séances de l'Academie des sciences 281, 467-469.

Schell, J., Montagu, M. van, Picker, A. De, Waele, D. De, Engler, G., Genetello, C., Hernalsteens, J. P., Holsters, M., Messens, E., Silva, B., Elsacker, S. van den, Larebeke, N. VAN \& ZAENEN, I. (1977). Crown gall: bacterial plasmids as oncogenic elements for eucaryotic cells. In Molecular Biology of Plants, symposium, University of Minnesota (in the 
Press). Edited by I. Rubinstein. St. Paul: University of Minnesota Press.

SCHILPEROORT, R. A. \& BomhoFf, G. H. (1975).

Crown-gall: a model for tumor research and genetic engineering. In Genetic Manipulations with Plant Materials. pp. I4I-I62. Edited by $L$. Ledoux. New York: Plenum Press.
SOBER, H. (editor) (1970). Handbook of Biochemistry. Selected Data for Molecular Biology, p. J234. Cleveland, Ohio, U.S.A.: C.R.C. Press.

Watson, B., Currier, T. C., Gordon, M. P., Chilton, M. D. \& Nester, E. W. (1975). Plasmid required for virulence of Agrobacterium tumefaciens. Journal of Bacteriology 123, 255-264. 